\title{
Study on Quality Evaluation of Master of Engineering Education System
}

\section{Construction}

\author{
Cun Yuan $\mathrm{Mu}^{1, a^{*}}$ and Ke Ding ${ }^{2, b}$ \\ Shenyang Jianzhu University, Liaoning, Shenyang,China \\ ysyz@sjzu.edu.cn, 200803896@qq.com
}

Keywords: Master of Engineering; Education; Quality; Evaluation System

\begin{abstract}
Constituent elements of master of engineering education quality evaluation system, is analyzed from aspects such as assurance of master of engineering dominant position, training conditions, supervisor team, management, four first-class indexes including education basis, management link, process control, education result; and its corresponding second-class index. Meanwhile master of engineering education quality evaluation system is constructed with second-class index decomposed into specific third-class index. The scoring of third-class index education basis evaluation is taken as an example to show the specific scoring for each item. As to master of engineering education quality evaluation index system, the practice result, weights parameter to be extended and improved, and others are described as reference for master of engineering education quality evaluation.
\end{abstract}

Analysis of Constituent Elements about Master of Engineering Education Quality Evaluation System

Master of engineering education quality results from factors like society, students, supervisors, management, and construction of training conditions. Their impacts should be analyzed comprehensively in the master of engineering education quality evaluation[1] .

Protecting Master of Engineering Dominant Position Is the Basis of the Education Quality Assurance. The quality of student pool is an important basis and premise of quality of education. However the structure of student pool, quantity and quality for masters of engineering are to be improved. Universities and enterprises should adhere to the people-oriented concept, and provide better environment and conditions of education and completely respect postgraduates' rights[2].

Excellent Education Conditions Is the Premise to Assure the Master of Engineering Quality. Master of engineering education needs support from the project with engineering background. With good training conditions, masters of engineering can perform practical service, and create some valuable results so as to completely improve the master of engineering education quality[3].

Supervisors are the Key to Master of Engineering Education Quality Assurance. It should be pointed out interdisciplinary or cross-school supervisors should be encouraged to instruct postgraduates. Integrated with engineering project, supervisors' collaboration and instruction can motivate themselves to improve their professional levels and focus on education quality of postgraduates[4].

Standardized Management Work Is an Important Assurance to Master of Engineering Education Quality. Relevant rules and regulations should be set and followed in the process of management. Systems of thesis proposal censorship, of mid-term report, of anonymous thesis 
anonymous review, and system of tutor avoidance should be adhered to consistently[5]. When they are strict with postgraduates, supervisors are required to set examples at the same time.

\section{Construction of Master of Engineering Postgraduate Education Quality Evaluation System}

Master of engineering postgraduate education is a systematic project, By analytic hierarchy process in this paper, the postgraduate education quality is decomposed into four first-class index such as education basis (B), management link (C), process control (D) and the education result (E). Weight coefficients are respectively $0.2,0.1,0.3,04$. The first-level index is divided into 16 second-class index[6]. The lay-out of postgraduate education quality evaluation is shown in Figure 1. The second-class index postgraduate education quality evaluation decomposition is demonstrated in Table 1.

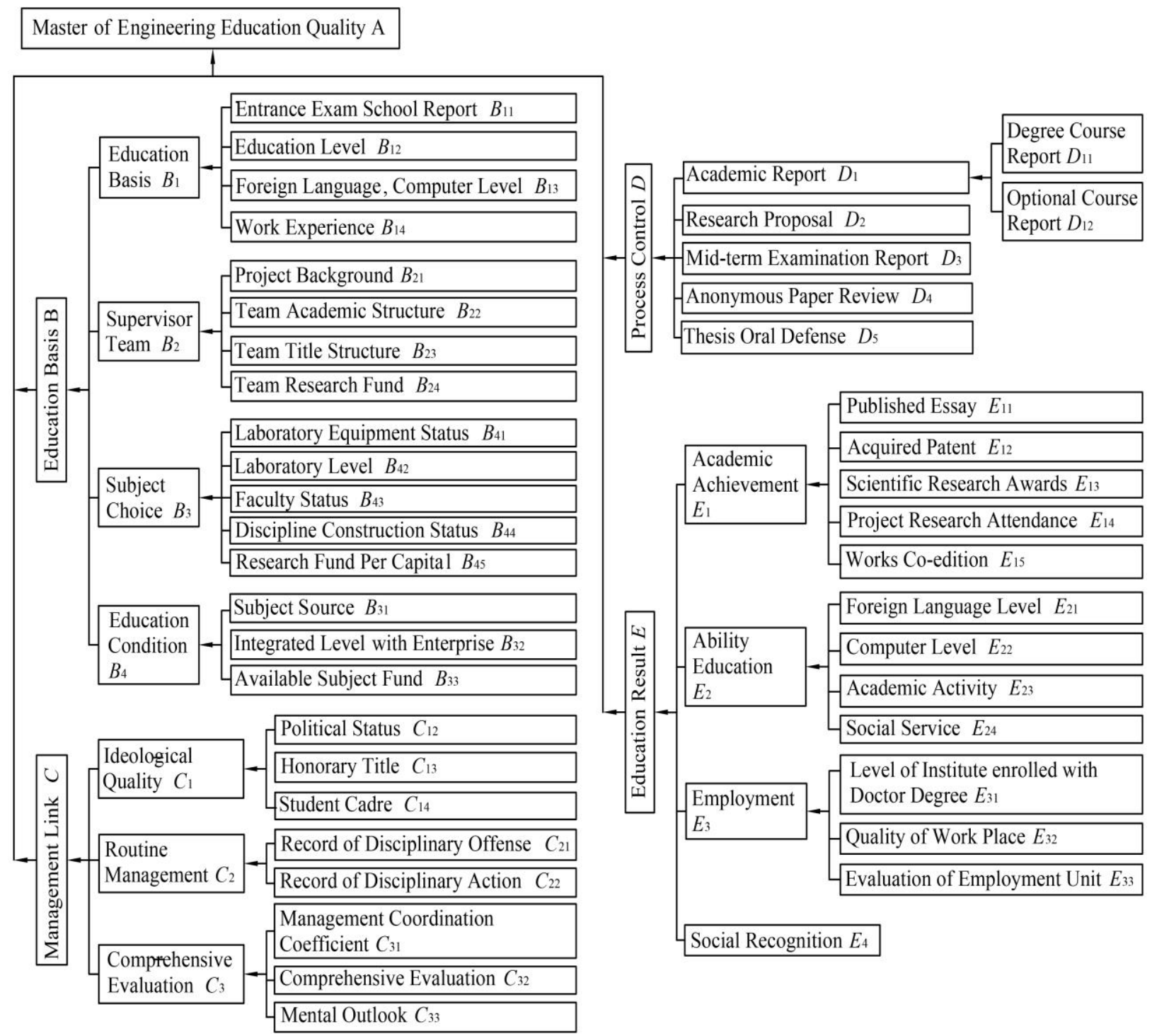

Figure 1. The Lay-out of Master of Engineering Education Evaluation System

Education Basis (B) is specifically evaluated from four aspects: Student Basis (B1), Supervisor Team (B2), Subject Choice (B3) and Education Condition (B4), of which weights are respectively $0.2,0.3,0.3$, and 0.2 , calculated as follows[7]:

$B_{1}=B_{11} B_{12} B_{13} B_{14}, \quad B_{2}=B_{21} B_{22} B_{23} B_{24}, B_{3}=B_{31} B_{32} B_{33}, \quad B_{4}=B_{41} B_{42} B_{43} B_{44} B_{45}$, $B=0.2 B_{1}+0.3 B_{2}+0.3 B_{3}+0.2 B_{4}$. 


\begin{tabular}{|c|c|}
\hline Three -class Index & Specific Scoring \\
\hline $\begin{array}{l}\text { Entrance Exam } \\
\text { School Report } B_{11}\end{array}$ & jerage score of subject under percentage grading system \\
\hline Education Level $B_{12}$ & $\begin{array}{l}\text { undergraduate attending entrance examination is } 1 \text {, graduate } 1.2 \text {, } \\
\text { dual degree } 1.1 \text {,undergraduate without attending entrance } \\
\text { examiantion0.9,junior college degree } 0.7 \text {, junior college degree below } 0.6\end{array}$ \\
\hline $\begin{array}{l}\text { English, Computer } \\
\text { level } B_{13}\end{array}$ & $\begin{array}{l}\text { College English Test Band } 4 \text { and National Computer Test Band } 2 \\
\text { is1,College English Test Band6 and National Computer Test Band } 3 \\
\text { above(below) respectively plus(minus) } 0.1\end{array}$ \\
\hline Work Experience $B_{14}$ & base is 1 , one more year plus 0.05 , the upper limit 1.2 \\
\hline $\begin{array}{l}\text { Project Background } \\
B_{21}\end{array}$ & base is 1 , one more person plus 0.05 , the upper limit 1.2 \\
\hline Team Academic & master is 1 , doctor 1.2 , und \\
\hline Structure $B_{22}$ & averaging \\
\hline $\begin{array}{l}\text { Team Title structure } \\
B_{23}\end{array}$ & $\begin{array}{l}\text { associate professor is } 1 \text {, professor } 1.2 \text {, lecturer } 0.8 \text {, lecturer below } 0.6 \text {, } \\
\text { total averaging }\end{array}$ \\
\hline Team Research Fund & average of 10,000 yuan a year per person is 1 , every other 10,000 yuan \\
\hline$B_{24}$ & $\begin{array}{l}\text { added plus } 0.1 \text {, the upper limit } 1.2 \text {,every other } 2,000 \text { yuan subtracted } \\
\text { minus } 0.1^{[8]}\end{array}$ \\
\hline Subject Source $B_{31}$ & $\begin{array}{l}\text { national level is } 1.4 \text {, provincial \& ministry level } 1.2 \text {, university's level 1.1, } \\
\text { lateral 1.0、optional } 0.8 \text { and others } 0.6\end{array}$ \\
\hline $\begin{array}{l}\text { Integrated Level } \\
\text { with Enterprise } B_{32}\end{array}$ & range between 0.8 to 1.2 \\
\hline Available Subject & 10,000 yuan is 1, every other 10,000 yuan adde \\
\hline Fund $B_{33}$ & 1.2 ; every other 2,000 yuan subtracted minus 0.1 \\
\hline Laboratory & range between 0.6 to 1.0 \\
\hline Equipment Status $B_{41}$ & \\
\hline $\begin{array}{l}\text { Laboratory Level } \\
B_{42}\end{array}$ & $\begin{array}{l}\text { national level is } 1.4 \text {,provincial ministry level } 1.2 \text {,university key } \\
\text { laboratory } 1 \text {, average laboratory } 0.8^{[9]}\end{array}$ \\
\hline $\begin{array}{l}\text { Faculty Status } B_{43} \\
\text { Discipline }\end{array}$ & $\begin{array}{l}\text { associate professor is } 1 \text {, professor } 1.1 \text {, lecturer } 0.8 \text {, lecturer below } 0.6 \\
\text { first-level discipline-based doctor degree program is } 1.4 \text {, first-level }\end{array}$ \\
\hline $\begin{array}{l}\text { Construction Status } \\
B_{44}\end{array}$ & $\begin{array}{l}\text { discipline-based master degree program 1.0; second-level discipline-based } \\
\text { doctor degree program1.2, second-level discipline-based master degree } \\
\text { program } 0.8\end{array}$ \\
\hline $\begin{array}{l}\text { Research Fund Per } \\
\text { Capital } B_{45}\end{array}$ & $\begin{array}{l}\text { average of } 10,000 \text { yuan a year per person is } 1 \text {, every other } 10,000 \text { yuan } \\
\text { added plus } 0.1 \text {, the upper limit is } 1.2 \text {; every other } 2,000 \text { subtracted minus } \\
0.1\end{array}$ \\
\hline
\end{tabular}

Table 1 Scoring of Three-class Index Education Basis Evaluation

Management Link (C) mainly contains three aspects: Ideological Quality(C1)、 Routine Management(C2)and Comprehensive Evaluation(C3), of which weights are respectively 0.4,0.3, 0.3 , calculated as follows:

$$
C_{1}=C_{11} C_{12} C_{13}, \quad C_{2}=C_{21} C_{22}, \quad C_{3}=C_{31} C_{32} C_{33},
$$

And Management Link is counted like this: $C=0.4 C_{1}+0.3 C_{2}+0.3 C_{3}$.

Process Control (D) mainly contains two stages, one for Master of Engineering courses study and the other for subject research[10]. It can be specifically divided into five aspects such as 
Academic Report (D1), Research Proposal (D2), Mid-term Examination Report (D3), Anonymous Paper Review (D4), and Thesis Oral Defense (D5), of which weights are respectively 0.2, 0.3, 0.15, $0.2,0.15$, calculated as follows:

$$
C_{1}=C_{11} C_{12} C_{13}, \quad C_{2}=C_{21} C_{22}, \quad C_{3}=C_{31} C_{32} C_{33},
$$

Education Result (E) is mainly measured by four indexes, such as indexes of Postgraduate Academic Achievement (E1), Postgraduate Ability Education (E2), Postgraduate Employment (E3), and of Social Recognition (E4), of which weights are respectively 0.35, 0.3, 0.2 0.15, calculated as follows:

$$
E=0.35 E_{1}+0.3 E_{2}+0.2 E_{3}+0.15 E_{4} .
$$

Among them: $E_{1}=E_{11} E_{12} E_{13} E_{14} E_{15}, E_{2}=E_{21} E_{22} E_{23} E_{24}, E_{3}=E_{31} E_{32} E_{33}$.

As is comprehensively analyzed above, available in Table 1(A) are Master of Engineering education quality, calculated as follows: $A=0.2 B+0.1 C+0.3 D+0.4 E$.

Being equal to 1 or so, A characterizes the quality of postgraduates educated in a certain condition of society, graduate, supervisor, administration and conditions of construction.

\section{Some Explanations for Master of Engineering Postgraduate Education Quality Evaluation System}

Practical Results. The above-mentioned weight indexes of each second-class index are for reference only. Universities should adjust it according to master of Engineering education goal and education characteristics and should reflect the level of Master of Engineering education specifically, scientifically and objectively. The Master of engineering postgraduate quality evaluation index system runs through the whole process, from the time before and after postgraduates are enrolled, to the time after postgraduates graduate. By calculating the above-mentioned index system, training quality (A) above 0.8 is defined as excellent, more than 0.6 qualified [11].

Weight Parameters to be Expanded and Improved. Index choice, the application of calculation and index weight coefficient of this evaluation system needs to put into consideration the actual situation in various other different universities and perfected them. Through the practical application, postgraduates from different universities, majors and grades are chosen as subjects, whose above-mentioned indexes are respectively traced and recorded, and then their scores are chosen in the corresponding method. Then the study results of experiment are compared with the actual situation, and the relevant parameters and weight coefficients of evaluation index system are corrected so as to achieve more objectively evaluated postgraduate education quality.

\section{The Evaluation System Is Only Applicable to the Individual Postgraduate Education}

Quality Evaluation. The evaluation system is mainly applied to quality evaluation of individual postgraduate. The groups data should be processed with relevant calculation for the evaluation of a university, college or a wider range groups of postgraduates. In addition, because a great many parameters are involved in the evaluation system, it will be a complicated calculation for larger groups of postgraduates. Since in the evaluation index system, all the components of the third-class index adopt the quantified method, and relevant soft wares are written with the help of computer and network technology, the status of each graduate education is reflected successful, instantly, and punctually[12].

References

[1] XUE Jing, ZHANG Jun, LIU Wei, Master of Engineering in Double Shift, J. Journal of Ningxia University (Humanities \& Social Sciences Edition). V01.32 No.1 (2011.1)227-229. 
[2] ZHAO Shi-kui, WEI Yun-xia, Studies of American Master of Engineering Graduate Education Structure, J. Academic Degrees \& Graduate Education. Vol.250 No.9(2013.9)58-62.

[3] SHI Ya-ling, DU Juan, Reflection on Developing Master of Engineering Education, J. Journal of South China University of Technology(Social Science Edition). Volume (Issue)(2009.11)70-79.

[4] SONG Dan, MIAO Guan-jun, Master of Engineering Education Based on Social Services, J. Modern Education Management)(2011.1)115-117.

[5] LI Guang Yu, Discussion on Ensuring Quality of Full-time Master of Engineering, J. Academic Degrees \& Graduate Education. Volume (Issue)(2010.9)19-22.

[6] HAI Song-mei, Reflections on Innovating Master of Engineering Education, J. Journal of Graduate Education. Volume (Issue)(2013,4)81-85.

[7] MENG Xiu-li, WU Zhuo-ping, YANG Lian-sheng, A Survey on the Controlling System of Stakeholders in the Engineering, J. Postgraduate Education Administration of workplace, J. Journal of Liaoning Normal University (Social Sciences Edition). Volume(Issue)(2014.4)530-535.

[8] SUN Xin-bo, YI Jia-jun, LIANG Xiao-ning, ZOU Ji-e, Chinese Master of Engineering

Education enlightened from European and American Master of Engineering Training Mode, J. Journal of Huang Gang Normal University. Volume (Issue)(2012,32)18-20.

[9]TANG Xiang, LIN Hong, TIAN Mi, Ma Liang, Some Feasible Measures for Constructing Master of Engineering Education Quality Assurance System, J. Jiaoyu Jiaoxue Luntan. Volume (Issue)(2012.18)137-139.

[10] WANG Ji, DU Jing, Analysis of Problems and Reasons in Engineering Master Education Management, J. Journal of Technology College Education. Volume (Issue)(2010.29)86-89.

[11]CHEN Xing-de, Wang Cui-e, WANG Sheng, American engineering graduate student education history, present situation and the theory of reflection, J. Academic Degrees \& Graduate Education. Volume(2011.6)72-77.

[12] Graduate education quality report compiled research group, Chinese Graduate Education Quality Annual Report, China Science and Technology Press, 2013. 